\title{
Analysis of the Factors Affecting the Choice of Support Policies Applied in Cotton Production by Analytical Hierarchy Process: The Case of 'Kahramanmaraş' Province
}

\begin{abstract}
In this study, it was aimed to determine the importance level of the factors that are effective in the choice of alternative support policies applied to cotton and to calculate the preference degrees according to each criterion of the cotton producers in Kahramanmaraş. In the study, the results of a face-to-face survey with 67 producers in Kahramanmaraş province were used. Within the scope of the research, the producers were asked to rate the difference in payment support, input support, direct payment support, and target price support policies, taking into account high yield, quality product, timely payment, and ease of marketing. It was determined that they would prefer the policy option that enables them to make the most profit when the factors to be taken into consideration by the producers while evaluating the support policies are examined. It has been seen that the most important criterion among the agricultural production aims of the producers is "raising the standard of living", the most important factor they will consider to increase production is "good price", and the most important factor they will consider in a policy to be implemented is "giving a good price". Producers have been found to prefer payment preferences with different priorities; difference payment and direct payment support in terms of providing a high yield, input support for providing quality products, and paying target price support at the appropriate time. Considering all supports, it has been
\end{abstract}

Gönderilme Tarihi : Kabul Tarihi

\section{Sorumlu Yazar} Serhan CANDEMIR serhan_candemir@hotmail.com

0000-0003-4248-7024 
determined that the producers prefer difference payment support first and input support second.

Keywords: Agricultural support, analytical hierarchy process, cotton

\section{INTRODUCTION}

Cotton has a great economic value in terms of cottonproducing countries with the added value and employment opportunities it creates. Cotton supplies raw materials to the cotton gin industry, the textile industry, the oil and feed industry, and the paper industry with its fiber, core, and lint. In the production of biodiesel, which is an alternative to petroleum and is increasing day by day, oil obtained from cottonseed oil is used as raw material (Anonymous, 2019).

In addition to its economic importance, cotton meets the basic raw material of many industries. It is used in the production of crude oil as cottonseed, linters, and cellulose in the chemical and war industry as well as the bed and filling industry while its fiber is used in textile and other industries to briefly mention these industries. Usage as acorn and pulp in animal feed is also common (Anonymous, 2020).

There are very few countries in the world that are suitable for cotton agriculture due to climate conditions. Turkey is among the countries that could be called a minority that can perform cotton farming. According to the data of the International Cotton Advisory Committee (ICAC) for the 2018/19 production season, Turkey is the eleventh country in the world in term of cotton production area, the second in terms of fiber cotton yield per unit area, and the sixth in terms of production volume.

The total area of cotton production of Turkey in 2019 was 4,778,681 da while total production was 2.2 million tons (TUIK, 2020). Turkey meets $8 \%$ of the total amount of cotton produced in the world with this amount production. These data indicate that Turkey is located in a significant position in the world in terms of cotton production. Among the most important cities in Turkey in terms of cotton production value, 'Şanlıurfa' takes first place with 813,258 tons in while 'Aydın' is located in second with 246,382 tons (TUIK, 2020). These provinces are followed by 'Diyarbakır' with 233,707 tons, 'Hatay' with 219,581 tons, and 'Adana' with 205,670 tons.
'Kahramanmaraş', which is one of the important production areas of cotton, has a very rich product range in terms of agricultural products due to its geographical location and being a transitional zone that has borders in three different basins (Candemir et al., 2017).

Kahramanmaraş city is an important source of income for producers in terms of its suitability to the climatic conditions for cotton production and meeting the raw material of the cotton industry. Cotton production, which constitutes the lowest step of the textile and ready-to-wear industry, is extremely important due to the export rate it has reached and its high share in the Gross National Product. It states that the share of cotton in the textile and ready-to-wear sector is $50 \%$ in the 2018 cotton report published by the Ministry of Commerce. This shows that cotton production should be increased in both Turkey and Kahramanmaraş.

Kahramanmaras is in $9^{\text {th }}$ place in cotton production in Turkey with 44,931 tonnes in 2018 , while in the $14^{\text {th }}$ with an amount of 23,692 tonnes in 2019 (TUIK, 2020). Among the reasons for the significant decrease in the cultivation areas of cotton, which is the raw material of the textile industry and has a widespread cultivation area, it could be said that the prices are not at the desired level and the farmers turn to different production activities as an alternative to cotton as a result of the fluctuations in prices.

Cotton is an important source of raw materials for both textile and food as well as other sectors and is an important power of national-international trade and industry. Therefore, cotton production has strategic importance for countries. Proper usage of this power will make a significant contribution to the sustainability of Turkey's agricultural industry (Cevheri and Şahin, 2020). For this reason, problems in cotton production should be eliminated as soon as possible with the necessary agricultural policies.

The most important factors on the quantity and quality characteristics of agricultural products are the inputs used in production and the technology level. However, even in the most developed countries, the level of technology cannot provide full assurance against the characteristics of the agricultural sector and the risks it faces, which requires the 
sector to be supported and protected. On the other hand, the long production process, low financial recycling rate, and insufficient fund accumulation and investments in the sector increase the importance of supports and incentives (Gül Yavuz et al., 2016).

The aims of cotton support policies can be listed as increasing producer income by stabilizing production and product prices; to enable futures and product exchanges to take a more active role in cotton markets; to provide raw materials to the textile segment at affordable prices; increasing competitiveness in international markets, increasing export opportunities; enabling rural development as well as harmonization with GATT (Customs Tariffs and Trade General Agreement) Agriculture Agreement and the European Union (Özüdoğru, 2005).

In the literature, it is possible to come across many studies in which analytical hierarchy processes are applied in agriculture. When the previous studies on analytical hierarchy process are examined, there are many studies on decision-making processes in agricultural production as well as intensive land use (Amini et al., 2020 Jain and Ramsankaran, 2019; Seyedmohammadi et al., 2019; Kumar et al., 2020; Morandi et al., 2020; Ramamurthy et al., 2020).

In the literature, it is possible to find many studies in which the analytical hierarchy process (AHP) is applied in agriculture. Mawampanga and Debertin (1996) examined biological breeding, conventional breeding, and organic breeding, which are included in alternative farming systems, using the analytical hierarchy method. Alphonce (1997) studied the applications of the analytical hierarchy process related to the agricultural problems of developing countries. Hayashi (2000) classified and evaluated the criteria and purposes used in modeling agricultural production. Günden and Miran (2008) used the analytical hierarchy process in determining the basic production decisions of farmers and their priorities for receiving support. Çobanoğlu and Işın (2009) took advantage of the analytical hierarchy process method in the evaluation and selection of agricultural research projects, while Altun and Demir (2015) in analyzing of the criteria that affect the organic farming system preference of organic dried fig producers. Özüdoğru et al. (2015) determined the importance level of the factors that are effective in the choice of alternative support policies applied to cotton, sunflower, and soybean producers in Turkey and their preference degrees according to each criterion by using the AHP method. Aydin et al. (2016) determined which source the farmers in the Thrace Region first applied to and benefited from while making their input usage decisions through the analytical hierarchy process. Gül Yavuz et al. (2016) reported the significance level of the factors that are effective in the choice of alternative support policies applied to wheat, grain, corn, and paddy producers in Turkey and their preference degrees according to each criterion with the AHP method. Kocaköse and Aktürk (2019) studied the production preferences of agricultural enterprises operating in the Kumkale Plain of Çanakkale province, through an analytical hierarchy process.

In this study, the business and socio-economic characteristics of cotton producers have been determined, and the factors that affect producer decisions in the choice of support policies considered to be effective in cotton production in Kahramanmaraş province are shown. Support policies for cotton production are considered as differential payment, input, direct payment, and target price policy. Difference payment support and input support are policy tools currently being implemented. Target price and direct payment are support policy tools implemented in the past and are not available today. In this study, the reasons for cotton producers to prefer both current supports and supports that are not used today will be put forward.

\section{MATERIAL AND METHOD}

\section{Material}

The main material of the study is the survey studies conducted with cotton enterprises in Kahramanmaraş province. In addition, national and international literature and statistics related to the subject were also used. 


\section{Method}

In the study, a survey was conducted according to the simple random sampling method with 67 cotton producers at a $10 \%$ tolerance level and $95 \%$ confidence bounds. The following formula was used in the simple random sampling method (Yamane, 1967).

$$
\mathrm{n}=\frac{N \times S^{2}}{(N-1) D^{2}+S^{2}}
$$

$$
\begin{aligned}
& n=\text { Total number of samples }(67,09) \\
& N=\text { Total number of enterprises }(1294) \\
& S^{2}=\text { Standard deviation }(488,41) \\
& D^{2}=(57,26) \\
& d \quad=\text { (tolerable error in population mean) }(14,83)
\end{aligned}
$$

In the analysis of the obtained data, basic calculation methods, such as average and percentage, and cross tables were used primarily.

The purposes of the producers to make agricultural production as well as the factors they would consider for a support policy to be applied and to increase their production, or to continue to it, were examined by using the 'best-worst analyses'. The Best-Worst method is a discrete selection model first developed in 1988 by Jordan Louviere. In this method, participants are shown a series of objects (items) and asked to show the most important and the least important (best / worst, most / least, etc.) of them. Survey questions for the Best-Worst approach are very easy to understand for most of the participant s. Furthermore, people are better able to distinguish the differences between extreme objects than those of a middling state. Because, the answers involve the selection of objects rather than the preferred statement, and there is no bias.

Analytical Hierarchy Process (AHP) method was used to determine the reasons for the producers to choose their support policies. AHP is a decision-making method used in solving complex problems for multiple criteria. It allows decision-makers to model complex problems in a hierarchical structure that shows the relationship between the main objective, criteria, sub-criteria, and options of the problem (Saaty et al., 2003). In decision-making with AHP, not only quantitative but also qualitative values can be taken into account (Cheng and $\mathrm{Li}, 2002$ ). AHP can also be explained as a decision-making and estimation method that is used if the decision hierarchy can be defined and gives the percentage distributions of decision points in terms of factors affecting the decision.

The first step of AHP is to decompose the decision problem into its basic components and to create a hierarchical structure. It helps the decision-maker to focus on the smaller parts of the relevant decision (Braunschweig and Becker, 2004). The main goal is at the top of the decision hierarchy, the criterion that will affect the quality of the decision at the lower level, and the decision options at the bottom (Figure 1). Paired comparisons constitute the second fundamental step of AHP. It means the comparison of two options/criteria with each other and is based on the judgment of the decision-maker. If the hierarchy contains 'n' elements, a total of $n(n-1) / 2$ paired comparisons are required. 
In paired comparison, how important the A criterion is compared to the $\mathrm{B}$ criterion is determined by the preference scale with 1-9 points shown in Table 1 . Values such as 2, 4, 6 , and 8 that are not included in the level of importance are intermediate. The calculation of the priority (relative importance) of each element compared is called synthesis. The synthesis phase includes the normalization. In the most common normalization method, the elements of each column are divided by the sum of that column. The row average of the obtained values is taken. At the last stage of AHP, the final decision is reached and the decision problem is solved. At this stage, a mixed vector of priorities is created that will serve as the ranking of decision options in achieving the main goal of the problem. The final priorities obtained are also called the scores of decision options (Günden and Miran, 2008).

Table 1. Standard preference scale used in AHP analysis.

\begin{tabular}{|l|l|}
\hline $\begin{array}{l}\text { Importance } \\
\text { Level }\end{array}$ & Definition \\
\hline 1 & Two criteria being equally important \\
\hline 3 & Moderately important one over another \\
\hline 5 & Strongly important \\
\hline 7 & Very strongly important \\
\hline 9 & Absolutely important \\
\hline $2,4,6,8$ & Intermediate values \\
\hline
\end{tabular}

It is also important to determine whether the comparisons are consistent. For this purpose, the consistency rate is calculated for each comparison. The consistency rate is required not to be more than 0.10 . A consistency ratio of more than 0.10 indicates either a calculation error in the AHP or the inconsistency of the decision-maker in the comparisons (Saaty, 2000). If the consistency rate is more than 0.10 , the decision-makers need to reconsider their judgments to reduce the consistency rate to the desired level.

$$
C I=\frac{\lambda-\mathrm{n}}{\mathrm{n}-1}
$$$$
C R=\frac{\mathrm{CI}}{\mathrm{RI}}
$$

CR: Consistency ratio

CI: Consistency index

RI: Random consistency index

\section{RESULTS AND DISCUSSION}

Socio-demographic characteristics of cotton producers were given in Table 2. The age of the producers ranged from 33 to 76 , with an average of 52.31 . The average education period of the producers is 6.46 years, and the average agricultural experience is 33.22 years. The average size of the households in the enterprises was found to be 5, and the average number of people working in agriculture in the household was 2. These results show that the average age of the producers in the study area is high and the use of domestic labor in agricultural activities is low.

Table 2. Socio-demographic characteristics of the producers

\begin{tabular}{|l|c|c|c|c|}
\hline $\begin{array}{l}\text { Socio-demograph- } \\
\text { ic characteristics }\end{array}$ & Average & $\begin{array}{c}\text { Standard } \\
\text { deviation }\end{array}$ & $\begin{array}{c}\text { Mini- } \\
\text { mum }\end{array}$ & $\begin{array}{c}\text { Maxi- } \\
\text { mum }\end{array}$ \\
\hline Age (years) & 52.31 & 9.89 & 33.00 & 76.00 \\
\hline $\begin{array}{l}\text { Duration of educa- } \\
\text { tion (years) }\end{array}$ & 6.46 & 2.49 & 0.00 & 11.00 \\
\hline $\begin{array}{l}\text { Agricultural experi- } \\
\text { ence (years) }\end{array}$ & 33.22 & 10.87 & 8.00 & 50.00 \\
\hline $\begin{array}{l}\text { Household size } \\
\text { person) }\end{array}$ & 5.00 & 2.30 & 1.00 & 11.00 \\
\hline $\begin{array}{l}\text { The number of } \\
\text { people working in } \\
\text { Agriculture in the } \\
\text { household (person) }\end{array}$ & 2.00 & 1.75 & 1.00 & 10.00 \\
\hline
\end{tabular}

The farmland refers to the total area where the farmer family produces, regardless of the ownership relationship, type of land, and usage patterns (Tatlidil, 1992). In addition, many studies (Rogers, 1983; Konyar and Osborn, 1990; Gül Yavuz, 2010) stated that the size of the business land has an effect on the producer decisions. The land ownership and usage status of agricultural enterprises were investigated as part of the study. The total size of the land cultivated by cotton producers was $27.92 \mathrm{ha}$, the share of the property land in the total cultivated land was 58.75 $\%$, the share of the land cultivated by rent was $38.05 \%$, and the share of the land cultivated by the partnership was $3.20 \%$. The share of irrigated land in the total land was $98.49 \%$, while the share of non-irrigated land was quite low and $1.51 \%$. 
Table 3. Land ownership and use status in businesses

\begin{tabular}{|l|c|c|}
\hline Land ownership status & Ha & \% \\
\hline Property land size & 16.40 & 58.75 \\
\hline Size of land cultivated by rent & 10.62 & 38.05 \\
\hline Size of land cultivated by sharecropping & 0.89 & 3.20 \\
\hline Enterprises land size & 27.92 & 100.00 \\
\hline Irrigated land size & 27.50 & 98.49 \\
\hline Non-irrigated land size & 0.42 & 1.51 \\
\hline Total land size & 27.92 & 100.00 \\
\hline
\end{tabular}

Cotton producers werealso asked about their agricultural production purposes. Producers have determined which of these aims is closest to agricultural production purposes and which is the furthest. Evaluations were made on average (B$\mathrm{W})$ values. The higher average $\mathrm{B}-\mathrm{W}$ value means the higher importance of the relevant feature. The feature with the largest positive value is interpreted as the most important feature and the value with the smallest negative value as the least important feature. When the average B-W value is zero, a moderately important property is being mentioned.
Table 4 includes the importance levels of the characteristics that producers consider while making agricultural production. Accordingly, it has been determined that the criterion "utilizing the money you have, your own time and family labor $(-0.33)$ " is the least important criterion among the producers' purposes of agricultural production while the most important is the criterion of "raising the standard of living (0.52)". Özüdoğru et al., (2015) uses the first criterion of "raising the standard of living" as the goal of agricultural production in their study with cotton-producing enterprises.

Table 4. Agricultural production purposes of cotton producers

\begin{tabular}{|l|c|c|c|c|c|c|c|}
\hline Purposes & B & $\mathbf{W}$ & $\mathbf{B}-\mathbf{W}$ & Sqrt (B/W) & $\begin{array}{c}\text { Std interval } \\
\text { scale }\end{array}$ & Average (B-W) & (B-W)/W*100 \\
\hline Taking good care of existing land & 6 & 2 & 4 & 1.73 & 40.28 & 0.06 & 200.00 \\
\hline Raising the standard of living & 37 & 2 & 35 & 4.30 & 100.00 & 0.52 & 1750.00 \\
\hline Minimal environmental pollution & 0 & 6 & -6 & 0.00 & 0.00 & -0.09 & -100.00 \\
\hline $\begin{array}{l}\text { Growing healthy products to protect } \\
\text { consumers }\end{array}$ & 0 & 11 & -11 & 0.00 & 0.00 & -0.16 & -100.00 \\
\hline Meeting family nutritional needs & 16 & 1 & 15 & 4.00 & 93.02 & 0.22 & 1500.00 \\
\hline Performing agriculture as a profession & 2 & 13 & -11 & 0.39 & 9.12 & -0.16 & -84.62 \\
\hline $\begin{array}{l}\text { Utilizing your money, your own time } \\
\text { and family labor }\end{array}$ & 2 & 24 & -22 & 0.29 & 6.71 & -0.33 & -91.67 \\
\hline $\begin{array}{l}\text { Contributing to the economy / produc- } \\
\text { tion of the country as much as possible }\end{array}$ & 4 & 8 & -4 & 0.71 & 16.44 & -0.06 & -50.00 \\
\hline
\end{tabular}

Table 5 contains the most significant and insignificant factors that cotton producers will consider to increase/ maintain production. According to Best-Worst analysis results, it has been seen that the most important factor that producers will consider to increase production is "good price (0.91)". "Good price" is the price level that can meet the expectations of the producers. The "easy to market $(-0.42)$ " purpose has been reported as the least important element that producers will consider to increase or continue their production. 
Table 5. The factors that cotton producers consider necessary to increase/maintain their production

\begin{tabular}{|l|c|c|c|c|c|c|c|}
\hline Factors & $\mathbf{B}$ & $\mathbf{W}$ & $\mathbf{B}-\mathbf{W}$ & $\begin{array}{c}\text { Sqrt } \\
(\mathbf{B} / \mathbf{W})\end{array}$ & $\begin{array}{c}\text { Std interval } \\
\mathbf{s c a l e}\end{array}$ & $\begin{array}{c}\text { Average } \\
(\mathbf{B}-\mathbf{W})\end{array}$ & $\begin{array}{c}(\mathbf{B}-\mathbf{W}) \\
/ \mathbf{W}^{*} \mathbf{1 0 0}\end{array}$ \\
\hline Good price & 62 & 1 & 61 & 7.87 & 100.00 & 0.91 & 6100.00 \\
\hline Eligible premium & 1 & 1 & 0 & 1.00 & 12.71 & 0.00 & 0.00 \\
\hline Easy loan finding & 0 & 2 & -2 & 0.00 & 0.00 & -0.03 & -100.00 \\
\hline Availability of fertilizers in desired time and amount & 1 & 8 & -7 & 0.35 & 4.49 & -0.10 & -87.50 \\
\hline Availability of fertilizers at affordable prices & 1 & 12 & -11 & 0.29 & 3.67 & -0.16 & -91.67 \\
\hline Suitability of pesticides & 0 & 0 & 0 & 0.00 & 0.00 & 0.00 & 0.00 \\
\hline Availability of prices & 0 & 4 & -4 & 0.00 & 0.00 & -0.06 & -100.00 \\
\hline $\begin{array}{l}\text { Availability of quality seed-seedlings at affordable } \\
\text { prices }\end{array}$ & 0 & 0 & 0 & 0.00 & 0.00 & 0.00 & 0.00 \\
\hline Availability of workers at any time & 0 & 9 & -9 & 0.00 & 0.00 & -0.13 & -100.00 \\
\hline Tool-machine can be easily obtained & 1 & 2 & -1 & 0.71 & 8.98 & -0.01 & -50.00 \\
\hline Easy to market & 1 & 29 & -28 & 0.19 & 2.36 & -0.42 & -96.55 \\
\hline
\end{tabular}

The most important and least important elements that producers will consider in a policy to be implemented were given in Table 6 . According to the data, the most important factor that producers will consider in a policy to be applied has been observed as "giving a good price (0.78)" while "it should focus on the extension support $(-0.45)$ " and "easy bureaucratic procedures" $(-0.31)$ were determined as the least significant factors. In the study conducted by Özüdoğru et al. (2015), it has been reported that the most important factor that cotton producers will consider in a support policy is "giving a good price". In addition, in the study conducted by Gül Yavuz et al. (2016), with grain corn producers, the most important criterion taken into consideration by the producers is "good price" and the second one is "supplying fertilizers at affordable prices", which is an important input. In capital-intensive agricultural production activities, producers set high sales prices and low input prices as a prerequisite. This shows that the producers want to create profit maximization and cost minimization components on the factors they can influence.

Table 6. The factors that cotton producers consider in a support policy to be implemented

\begin{tabular}{|l|c|c|c|c|c|c|c|}
\hline Factors & $\mathbf{B}$ & $\mathbf{W}$ & $\mathbf{B}-\mathbf{W}$ & $\begin{array}{c}\text { Sqrt } \\
(\mathbf{B} / \mathbf{W})\end{array}$ & $\begin{array}{c}\text { Std interval } \\
\text { scale }\end{array}$ & $\begin{array}{c}\text { Average } \\
(\mathbf{B}-\mathbf{W})\end{array}$ & $\begin{array}{c}(\mathbf{B}-\mathbf{W}) \\
/ \mathbf{W}^{*} \mathbf{1 0 0}\end{array}$ \\
\hline Should focus on input support & 1 & 1 & 0 & 1.00 & 13.74 & 0.00 & 0.00 \\
\hline Should focus on credit support & 0 & 5 & -5 & 0.00 & 0.00 & -0.07 & -100.00 \\
\hline Should focus on extension support & 1 & 31 & -30 & 0.18 & 2.47 & -0.45 & -96.77 \\
\hline Should focus on marketing facilities & 2 & 1 & 1 & 1.41 & 19.43 & 0.01 & 100.00 \\
\hline Should give weight to yield increase & 4 & 1 & 3 & 2.00 & 27.47 & 0.04 & 300.00 \\
\hline Should increase employment & 0 & 2 & -2 & 0.00 & 0.00 & -0.03 & -100.00 \\
\hline Should improve product quality & 6 & 1 & 5 & 2.45 & 33.65 & 0.07 & 500.00 \\
\hline Should give good price & 53 & 1 & 52 & 7.28 & 100.00 & 0.78 & 5200.00 \\
\hline Should be premium based & 2 & 2 & 0 & 1.00 & 13.74 & 0.00 & 0.00 \\
\hline $\begin{array}{l}\text { Should provide easy bureaucratic proce- } \\
\text { dures }\end{array}$ & 1 & 22 & -21 & 0.21 & 2.93 & -0.31 & -95.45 \\
\hline
\end{tabular}


The producers were asked to rate agricultural supports such as the different payment support, input support, direct payment support, or target price support policies by taking into account high yield, high profit, timely payment, and easy marketing.

Paired comparisons have been made for the criteria that affect cotton producers to choose the difference payment support. Percentage distribution of importance of decision criteria and weighted scores of decision criteria were calculated with the help of the matrix formed as a result of paired comparisons between criteria. As a result of the consistency analysis, it was seen that there was no discrepancy at the $10 \%$ significance level.
The most important decision criterion for the producers' choice of different payment support is high yield with a value of 0.389 . The criteria for cotton producers to prefer difference payment support include ease of marketing $(0.281)$ in the second, providing quality products $(0.172)$ in the third, and payment at the appropriate time (0.159) is the last (Table 7). In their study with sunflower producing businesses, Top and Özüdogru (2016) determined that among the most important decision criteria of the producers in the adoption of supports, high profit is the first and the appropriate payment time is the second. In their study with cotton producers, Özüdogru et al. (2015), on the other hand, found that among the decision criteria of the producers to choose the difference payment support, the high yield was the first and high profit was the second.

Table 7. Percentage distribution of importance and weighted scores of preference reasons for difference payment support

\begin{tabular}{|l|c|c|c|c|c|}
\hline & \multicolumn{5}{|c|}{ Criterion } \\
\hline Criteria & High yield & Quality product & Ease of marketing & Payment at appropriate time & Row average \\
\hline High yield & 0.364 & 0.571 & 0.286 & 0.333 & $\mathbf{0 . 3 8 9}$ \\
\hline Ease of marketing & 0.364 & 0.143 & 0.286 & 0.333 & $\mathbf{0 . 2 8 1}$ \\
\hline Quality product & 0.091 & 0.143 & 0.286 & 0.167 & $\mathbf{0 . 1 7 2}$ \\
\hline Payment at appropriate time & 0.182 & 0.143 & 0.143 & 0.167 & $\mathbf{0 . 1 5 9}$ \\
\hline \multicolumn{7}{|l|}{$\mathrm{N}=4, \mathrm{RI}=0.882, \lambda=4.1873, \mathrm{CI}=0.0624, \mathrm{CR}=0.0708$} \\
\hline
\end{tabular}

The distribution of importance and weighted scores of the criteria that are effective in the producers' choice of input support was given in Table 8 . As a result of the consistency analysis, it was determined that there was no discrepancy at the $5 \%$ significance level $(\mathrm{CR}=0.0229)$. The main reasons for cotton producers to prefer input support include the criteria of providing high-quality products $(0.338)$ primarily, providing high yield (0.288) secondly, providing ease of marketing (0.205) thirdly, and timely payment (0.169) as last. With this result, Gül Yavuz et al., (2016) in their study, high-profit criterion is the first of the criteria for choosing input support of grain corn producers. Since grain corn production is a relatively less capital-intensive production activity than cotton production, input support is perceived as a profit criterion. On the other hand, it can be said that cotton production is perceived as a support to be used in financing the inputs that will provide quality production.

Table 8. Percentage distribution of importance and weighted scores of preference reasons for input support

\begin{tabular}{|l|c|c|c|c|c|}
\hline & \multicolumn{5}{|c|}{ Criterion } \\
\hline Criteria & High yield & Quality product & Ease of marketing & Payment at appropriate time & Row average \\
\hline Quality product & 0.286 & 0.333 & 0.400 & 0.333 & $\mathbf{0 . 3 3 8}$ \\
\hline High yield & 0.286 & 0.333 & 0.200 & 0.333 & $\mathbf{0 . 2 8 8}$ \\
\hline Ease of marketing & 0.286 & 0.167 & 0.200 & 0.167 & $\mathbf{0 . 2 0 5}$ \\
\hline Payment at appropriate time & 0.143 & 0.167 & 0.200 & 0.167 & $\mathbf{0 . 1 6 9}$ \\
\hline \multicolumn{7}{|c|}{$\mathrm{N}=4, \mathrm{RI}=0.882, \lambda=4.0607, \mathrm{CI}=0.0202, \mathrm{CR}=0.0229$} \\
\hline
\end{tabular}


The distribution of importance and weighted scores of the criteria that are effective for the producers to prefer direct payment support was given in Table 9. According to the data taken from consistency analysis, It was seen that there was no discrepancy at the $5 \%$ significance level $(C R=0.0174)$. Cotton producers prefer direct payment support primarily because of its high yield (0.356). Among the reasons for preference, the criteria of providing quality products $(0.325)$ secondarily, providing ease of marketing thirdly (0.194), and last payment at the appropriate time $(0.125)$ are the criteria.

Table 9. Percentage distribution of importance and weighted scores of preference reasons for direct payment support

\begin{tabular}{|l|c|c|c|c|c|}
\hline & \multicolumn{5}{|c|}{ Criterion } \\
\hline Criteria & High yield & Quality product & Ease of marketing & Payment at appropriate time & Row average \\
\hline High yield & 0.353 & 0.333 & 0.364 & 0.375 & $\mathbf{0 . 3 5 6}$ \\
\hline Quality product & 0.353 & 0.333 & 0.364 & 0.250 & $\mathbf{0 . 3 2 5}$ \\
\hline Ease of marketing & 0.176 & 0.167 & 0.182 & 0.250 & $\mathbf{0 . 1 9 4}$ \\
\hline Payment at appropriate time & 0.118 & 0.167 & 0.091 & 0.125 & $\mathbf{0 . 1 2 5}$ \\
\hline \multicolumn{2}{|r|}{$\mathrm{N}=4, \mathrm{RI}=0.882, \lambda=4.0459, \mathrm{CI}=0.0153, \mathrm{CR}=0.0174$} \\
\hline
\end{tabular}

The criteria that are effective in the producers' preference of target price support have also been identified (Table 10). As a result of the consistency analysis, it was determined that there was no discrepancy at the $10 \%$ significance level (CR $=0.0702)$. Producers prefer target price support primarily because of the payment at appropriate time $(0.295)$ and quality product (0.254). Among the preference options, high efficiency (0.239) is in the third place, while ease of marketing (0.212) is in the last place.

Table 10. Percentage distribution of importance and weighted scores of preference reasons for target price support

\begin{tabular}{|l|c|c|c|c|c|}
\hline & \multicolumn{5}{|c|}{ Criterion } \\
\hline Criteria & High yield & Quality product & Ease of marketing & Payment at appropriate time & Row average \\
\hline Payment at appropriate time & 0.250 & 0.444 & 0.200 & 0.286 & $\mathbf{0 . 2 9 5}$ \\
\hline Quality product & 0.250 & 0.222 & 0.400 & 0.143 & $\mathbf{0 . 2 5 4}$ \\
\hline High yield & 0.250 & 0.222 & 0.200 & 0.286 & $\mathbf{0 . 2 3 9}$ \\
\hline Ease of marketing & 0.250 & 0.111 & 0.200 & 0.286 & $\mathbf{0 . 2 1 2}$ \\
\hline \multicolumn{7}{|r|}{$\mathrm{N}=4, \mathrm{RI}=0.882, \lambda=4.1857, \mathrm{CI}=0.0619, \mathrm{CR}=0.0702$} \\
\hline
\end{tabular}

In the study conducted by Özüdoğru et al. (2015), it was determined that cotton producers preferred the difference payment, one-time payment, and target price supports primarily because of high profit, and input support primarily because of payment at the appropriate time.

Preference degrees of alternative support policies applied in cotton production were given in Table 11. There was no discrepancy at the $10 \%$ significance level $(C R=0.0913)$ according to the result of the consistency analysis. It was seen that producers prefer difference payment support first, input support (0.314) second, target price support (0.202) third, and direct payment support (0.149) last.

In the study conducted by Özüdoğru et al. (2015), it was reported that cotton producers prefer difference payment support first, target price support second, one-time payment support third, and input support last. Considering the applied and alternative supports, sunflower producers 
seem to prefer target price support first, one-time payment support second, difference payment support third, input support last. Soy producers, on the other hand, prefer one-time payment support in the first place, target price support in the second place, difference payment support in the third place, and input support in the last place.

Table 11. Preference degrees of support policies

\begin{tabular}{|l|c|c|c|c|c|}
\hline & \multicolumn{4}{|c|}{ Criterion } \\
\hline Policies & $\begin{array}{c}\text { Difference payment } \\
\text { support }\end{array}$ & Input support & Direct payment support & Target price support & Row average \\
\hline $\begin{array}{l}\text { Difference payment sup- } \\
\text { port }\end{array}$ & 0.333 & 0.522 & 0.286 & 0.200 & $\mathbf{0 . 3 3 5}$ \\
\hline Input support & 0.167 & 0.261 & 0.429 & 0.400 & $\mathbf{0 . 3 1 4}$ \\
\hline Target price support & 0.333 & 0.130 & 0.143 & 0.200 & $\mathbf{0 . 2 0 2}$ \\
\hline Direct payment support & 0.167 & 0.087 & 0.143 & 0.200 & $\mathbf{0 . 1 4 9}$ \\
\hline & $\mathrm{N}=4, \mathrm{RI}=0.882, \lambda=4.2415, \mathrm{CI}=0.0805, \mathrm{CR}=0.0913$ & \\
\hline
\end{tabular}

\section{CONCLUSION}

In this study, the importance levels of the factors that are applied to cotton and that affect the choice of alternative support policies of the cotton producers in Kahramanmaraş province were determined and their preference levels were calculated.

It has been determined that the most important factor that cotton producers consider to continue their production is the good price, and the appropriate premium is moderately important. This finding reveals that different payment supports are an important factor in terms of the sustainability of production.

The most insignificant elements that producers consider in a support policy to be implemented are the ease of the bureaucratic procedures of the supports and the fact that the support policy is mainly on extension support. The insignificance of the factor that supports policies are predominant on extension support can be interpreted as the need for extension studies on the support policies, as well as the lack of perception of the producers about the support policies and the need to develop extension services. When the support policies discussed are evaluated according to producer preferences, it has been determined that cotton producers prefer the difference payment support primarily. It is possible to verify giving the highest premium to cotton compared to other products in different payment supports as the reason why producers prefer different payment support in the first degree.

The fact that input supports take second place among the agricultural supports in producer preferences and are seen as a medium important element in any agricultural support policy to be implemented indicates that these supports are an important support element for producers and should be reviewed in terms of implementation principles.

The lower rate of target price and direct payment supports, which are among the outdated agricultural support tools, indicates that these supports have lost their effectiveness in today's conditions.

Cotton production is not only a capital-intensive production activity but also competes internationally. In addition to the structural characteristics of agriculture, support for producers is required due to the intensity of cotton production activity. It was concluded that the aforementioned supports should have a characteristic that increases quality and yield in order to be effective in terms of both producers and public budgets. In addition, a support policy strategy should be followed to prevent producers from losing income due to negative fluctuations in product prices.

Research and Publication Ethics were followed in the editing, data collection, and writing stages of the study. 


\section{REFERENCES}

Alphonce, C. 1997. Application of the Analytic Hierarchy Process in Agriculture in Developing Countries. 53(1): $97-112$.

Altun, A., Demir, Y. 2015. Analitik Hiyerarşi Prosesi Yöntemi ile Tarımsal Araştırma Projelerinin Değerlendirilmesi ve Seçimi. Toprak Su Dergisi, 4(2): 41-48.

Amini, S., Rohani, A., Aghkhani, M.H., Abbaspour-Fard, M.H., Asgharipour, M.R., 2020. Assessment of land suitability and agricultural production sustainability using a combined approach (Fuzzy-AHP-GIS): A case study of Mazandaran province, Iran, Information Processing in Agriculture, Volume 7, Issue 3, Pages 384-402, ISSN 2214-3173, https://doi.org/10.1016/j. inpa.2019.10.001.

Anonymous, 2019. TicaretBakanlığı2018YılıPamukRaporu. https://ticaret.gov.tr/data/5d41e59913b87639ac9e02e8/ d0e2b9c79234684ad29baf256a0e7dce.pdf (Last access date: 20.10.2020)

Anonymous, 2020. http://www.taris.com.tr/pamukweb/t pamuk_hak.asp (Last access date: 20.10.2020).

Aydın, B., Unakıtan, G., Hurma, H., Azabağaoğlu, Ö., Demirkol, C., Yılmaz, F. 2016. Bitkisel Üretimde Çiftçilerin Girdi Kullanım Kararlarının Analizi: Trakya Bölgesi Örneği. U.Ü. Ziraat Fakültesi Dergisi, 30(2): 45-56.

Braunschweig, T. and B. Becker. 2004. Choosing research priorities by using the analytic hierarchy process: an application to international agriculture. $\mathrm{R} \& \mathrm{D}$ Management, 34(1):77-86.

Candemir, S., Kızılaslan, N., Kızılaslan, H., Uysal, O., Aydoğan, M. 2017. Kahramanmaraş İlinde Dane Mısır ve Pamuk Üretiminde Girdi Gereksinimi ve Karlılıkları Açısından Karşılaştırmalı Analizi. Türk Tarım ve Doğa Bilimleri Dergisi, 4(1): 1-8.

Cevheri, C.İ, Şahin, M. 2020. Dünya’da ve Türkiye'de Pamuk Üretiminin Tekstil Sektörü Açısından Önemi, Harran Üniversitesi Mühendislik Dergisi, 5(2): 71-81.

Cheng, E.W.L., Li, H. 2002. Construction Partnering Process and Associated Critical Success Factors:
Quantitative Investigation. Journal of Management in Engineering, 18(4): 194-202.

Çobanoğlu, F., Işın, F. 2009. Organik Kuru İncir Üreticilerinin Organik Tarım Sistemi Tercihini Etkileyen Kriterlerin Analitik Hiyerarşi Süreci ile Analizi. Tarım Ekonomisi Dergisi, 15 (2): 63-71.

Gül Yavuz, G., 2010. Polatlı İlçesinde Üreticilerin Tarım Sigortası Yaptırmaya Karar Verme Sürecinde Etkili Olan Faktörlerin Analizi. Tarım Bilimleri Dergisi, 11(2): 133-138.

Gül Yavuz, G., Miran, B., Bahadır Gürer, B., Yürekli Yüksel, N., Demir, A. 2016. Buğday, Dane Misır ve Çeltik Üretiminde Fark Ödemesi Desteklerinin Etkisi. TEPGE Yayın No: 266. ISBN: 978-605-9175-39-5.

Günden, C., Miran, B. 2008. "Çiftçilerin Temel İşletmecilik Kararlarının Öncelik ve Destek Alma Açısından Analizi. Tekirdağ Ziraat Fakültesi Dergisi, 5(2): 67-80.

Hayashi, K. 2000. Multicriteria Analysis for Agricultural Resource Management: A Critical Survey and Future Perspectives. European Journal of Operational Research. 122(2): 486-500.

ICAC, 2020. https://icac.org/ (Last access date: 20.10.2020).

Jain, P., Ramsankaran, R., 2019. GIS-based integrated multi-criteria modelling framework for watershed prioritisation in India - A demonstration in Marol watershed. Journal of Hydrology, Vol 578, ISSN 00221694, https://doi.org/10.1016/j.jhydrol.2019.124131.

Kocaköse, B., Aktürk, D. 2019. Evaluation of Production Preferences and Production Costs of Agricultural Enterprises in Çanakkale. Turkish Journal of Agriculture-Food Science and Technology. 7(11): 1990- 2000.

Konyar, K., Osborn, C.T., 1990. A National -Level Economic Analysis of Conservation Reserve Program Prticipation: A Discrete Choice Approach. Journal of Agricultural Economics Research, United States Department of Agriculture, Economic Research Service, Vol 42 (2): 1-8

Kumar, A., Pramanik, M., Chaudhary, S., Negi, M.S., 2020. Land evaluation for sustainable development of 
Himalayan agricultureusing RS-GIS in conjunction with analytic hierarchy process and frequency ratio. Journal of the Saudi Society of Agricultural Scinences, ISSN 1658-077X, https://doi.org/10.1016/j. jssas.2020.10.001

Louviere, J.J., 1988. Conjoint Analysis Modelling of Stated Preferences: A Review of Theory, Methods, Recent Developments and External Validity, Journal of Transport Economics and Policy 22 (1) 93-119.

Mawampanga, M.N., Debertin, D.L. 1996. Choosing Between Alternative Farming Systems: An Application of the Analytic Hierarchy Process. Review of Agricultural Economics (USA). 18(3): 385- 401.

Morandi, D.T., França, L.C.J., Menezes, E.S., Machado, E.L.M., Silva, M.D., Mucida, D.P., 2020. Delimitation of ecological corridors between conservation units in the Brazilian Cerrado using a GIS and AHP approach. Ecological Indicators (115) 106440. ISSN 1470-160X, https://doi.org/10.1016/j.ecolind.2020.106440.

Özüdoğru, T. 2005. Türkiye'de Pamukta Uygulanan Destekleme Politikaları. Tarımsal Ekonomi Araştırma Enstitüsü, T.E.A.E.-Bakış, Sayı 8, Nüsha 12.

Özüdoğru, T., Miran, B., Taşkaya Top, B., Uçum, İ. 2015. Pamuk, Ayçiçeği, Soya Üretiminde Fark Ödemesi Desteklerinin Etkisi. TEPGE Yayın No: 262. ISBN: 978-605-9175-34-0.

Ramamurthy, V., Obi Reddy, G.P., Kumar, N., 2020. Assessment of land suitability for maize (Zea mays L) in semi-arid ecosystem of southern India using integrated AHP and GIS approach, Computers and Electronics in Agriculture, Vol. 179, 105806, ISSN 0168-1699, https://doi.org/10.1016/j.compag.2020.105806.

Rogers, E.M., 1983. Diffusion of İnnovation. $3^{\text {rd }}$ Edition, The Free Press, 453 p., New York USA.

Saaty, T.L. 2000. Fundamentals of Decision Making and Priority Theory with the Analytic Hierarchy Process (Analytic Hierarchy Process Series, Vol. 6). RWS Publications, Pittsburgh.

Saaty, T.L., Vargas, L.G., Dellmann, K. 2003. The Allocation of Intangible Resources: The Analytic Hierarchy Process and Linear Programming. Socio-Economic Planning Sciences. 37(3): 169-184.

Seyedmohammadi, J., Sarmadian, F., Jafarzadeh, A.A., McDowell, R.W., 2019. Development of a model using matter element, AHP and GIS techniques to assess the suitability of land for agriculture, Geoderma, Vol. 352, Pages 80-95, ISSN 0016-7061, https:/doi. org/10.1016/j.geoderma.2019.05.046.

Tatlıdil, F. 1992. Konya İli Sulu ve Kuru Koşullardaki Tarım İşletmelerinde İşücü, Döner Sermaye ve Traktör Güçlerine Göre Optimal İşletme Büyüklüğünün Tespiti Ankara Üniversitesi Fen Bilimleri Enstitüsü, Doktora Tezi, Ankara.

Top Taşkaya, B., Özüdoğru, T., 2016. Türkiye’de Ayçiçeği Destekleme Politikalarının Tercihinde Etkili Olan Faktörlerin Belirlenmesi, Tarım Ekonomi Araştırmaları Dergisi, Vol:2 (2): 1-10

TUIK, 2020. https://www.tuik.gov.tr/ (Last access date: 20.10.2020).

Yamane, T. 1967. Elementary Sampling Theory Prentice. Hall Inc., Englewood Cliffs, N.J.,USA. 